\title{
Teacher Learming in Second Language Teacher Education: A Socially-Situated Perspective
}

\author{
Karen E. Johnson \\ The Pennsylvania State University \\ Donald Freeman \\ School for International Training
}

\begin{abstract}
Ultrapassadando as tradições históricas e teóricas que têm definido a educação de professores de segunda língua na América do Norte nos últimos vinte cinco anos, argumentamos neste artigo em favor de uma reconceituação do conhecimento de base da educação de professores de segunda língua. Ao mesmo tempo que reconhecemos que o ensino de diferentes línguas é moldado por suas respectivas culturas e literaturas, encontramos deficiências comuns ao definir o que os professores de segunda língua necessitam saber e ser capazes de fazer para ensinar com sucesso. Propomos olhar o professor como um aprendiz do ensino, as escolas e o ambiente escolar como contextos sócio-históricos nos quais a formação do professor e o próprio ensino acontecem, e o ensino de língua e a aprendizagem de língua como atividades que são implantadas nesse contexto. De forma conjunta, esses três domínios formam uma estrutura tripartite que utilizamos para elaborar uma nova visão epistemológica que considera o ensino de segunda língua como realmente ocorre.
\end{abstract}

Over the past decade, researchers and practitioners in the field of second language teacher education have publicly questioned the historical and theoretical traditions that have defined the knowledge-base of second language teacher education (Freeman \& Johnson, 1998; Freeman \& Richards, 1996; Richards \& Nunan, 1990). As the profession struggles to articulate its self-definition, it faces two deceptively simple questions: What is it that second language teachers need to know in order to do the work of this profession? and how is this knowledge best learned by individuals who wish to become members of this profession?

In second language teacher education in North America, we have not spent much time thinking about these questions, nor have we actively pursued and defined our own forms of knowledge. Instead, we have 
relied on the familiar forms of research and documentation of our parent disciplines of applied linguistics, theoretical linguistics, psychology, and less centrally, education, anthropology, and sociology. We have taken the core of second language teacher education to be mostly disciplinary knowledge: knowledge about how second languages are acquired, about how the English language is structured and used, about how people interact and communicate, and so on. Unfortunately, however, much of this disciplinary knowledge has not entered the domain of the classroom and remains largely dysfunctional to teachers themselves (Clarke, 1994).

\section{A knowledge-transmission perspective}

More than two decades ago, this same criticism was levied against general teacher education in North America. Historically, the education of teachers has been predicated on the notion that knowledge about teaching and learning can be "transmitted" to teachers by others, usually in the form of theoretical readings, university-based lectures, and/or professional development workshops which often take place outside the walls of the classroom. This design of teacher education has its roots in the process-product paradigm that anchored research and knowledge production in education beginning in the 1950's.

The process-product paradigm (Dunkin \& Biddle, 1974), which is more commonly known as "knowledge transmission", finds its historical and theoretical roots in cognitive learning theories. These theories have defined learning as an internal psychological process isolated in the mind of the learner as an individual, and largely free from the social and physical contexts within which it occurs (Lenneberg, 1967). Learned ideas are transported from one place to another. For this reason, this paradigm has focused on notions of transfer in learning to probe how knowledge travels from one setting or context to another. It has thus tended to see classrooms and formal schooling as "a site for decontextualized knowledge so that, abstracted, such knowledge may become general and hence generalizable, thus transferable to situations of use in the "real' world" (Lave, 1997: 18).

The knowledge-base of second language teacher education in North America has been historically and theoretically grounded in this paradigm; it has thus traditionally been compartmentalized into isolated theoretical courses and separated from teaching, leading to what teacher 
educator Ball (2000: 242) has referred to as "the persistent divide between subject matter and pedagogy". Most language teacher education programs operate under the assumption that it is necessary to provide teachers with discrete amounts of disciplinary knowledge, usually in the form of general theories and methods that are assumed to be applicable to any teaching context.

This view of teacher learning leads to "front-loading" (Freeman, 1993) in teacher education: the notion that teachers can be equipped in advance, at the start of their careers, for all that they will need to know and be able to do throughout their teaching lives. Learning to teach is viewed as learning about teaching in one context (the teacher education program), observing and practicing teaching in another (the practicum), and eventually, developing effective teaching behaviors in yet a third context (usually in the induction years of teaching). Again, Ball (2000: 243) summarizes the problem very succinctly: "a fundamental problem in learning to teach [is that], despite its centrality, usable content knowledge is not something teacher education, in the main, provides effectively". Thus, most of what teachers learn actually occurs in on-the-job initiation into the practices of teaching, and less so in professional teacher education programs (Freeman \& Johnson, 1998; Johnson, 1996).

\section{Current research on teacher learning}

Current research on how teachers learn to teach and how they carry out their work provides a very different conceptualization of what is worth knowing in teaching and how it is best learned. Much of this research recognizes that learning to teach is shaped by teachers' experiences, some figuring more prominently than others. More importantly, usable knowledge in teaching requires knowledge about oneself as a teacher, about the content to be taught, about students, about classroom life, and about the contexts within which teachers carry out their work (Connelly \& Clandinin, 1995; Elbaz, 1983; Freeman, 1996; Johnson, 1999; Shulman, 1987, Telles, 2000). This line of research also acknowledges that since teachers' knowledge of teaching is constructed through experiences in and with students, parents, colleagues and administrators, we can say that the processes of learning to teach are 'socially negotiated'. Moreover, teacher learning is normative and life- 
long; it is built through experiences in multiple social contexts first as learners in classrooms and schools, then later as participants in professional teacher education programs, and ultimately in the communities of practice in which teachers work (Lortie, 1975; Grossman, 1990; Chaklin \& Lave, 1996). Ultimately, learning to teach can be conceptualized as a longterm, complex, developmental process that is the result of participation in the social practices and contexts associated with learning and teaching.

Research on teachers' classroom practices finds that teachers think about their work in complex ways shaped by "practical theories" (Elbaz, 1983 ) or what Handal \& Luvas (1987) described as "appreciative systems". These theories or systems intermingle teachers' personal experiences as students, teachers, and language learners with knowledge of abstract theories and guiding principles from professional training, and teachers' personal values and beliefs. However, teachers' practical theories do not operate in isolation but are sensitive to the ways that the contexts in which teachers work influence their practices. Simply put, teachers' practical theories represent the complex ways in which teachers figure out what to do about a particular topic, with a particular group of students, in a particular time and place (Johnson, 1999). Given this embedded view, how teachers actually use their knowledge in classrooms has come to be seen as highly interpretive, socially negotiated, and continually restructured within the classrooms and schools where teachers work.

\section{A socially-situated perspective on teacher learning}

Such reconceptualizations of how teachers learn to teach and how they carry out their work in classrooms highlight the fundamentally social nature of cognition and learning. Theories of situated cognition argue that knowledge entails lived practices not just accumulated information (Lave \& Wenger, 1991; Chaiklin \& Lave, 1996). A socially-situated view of knowledge argues that the processes of learning are negotiated with people in what they do, through experiences in the social practices associated with particular activities (Lave \& Wenger, 1991; Cobb \& Bowers, 1999). Thus, this view of learning to teach is based on assumptions that knowing, thinking, and understanding come from the practice of leaming and teaching in specific classroom and school situations 
(Lave, 1997) or what Ball has called "the core activities of teaching" (2000: 243).

Therefore, if teacher learning and teaching are understood to grow out of participation in the social practices in classrooms, then what teachers know and how they use that knowledge in classrooms becomes highly interpretative and contingent on knowledge of self, setting, students, curriculum, and community. A socially-situated view of teacher learning argues that teacher education must reshape the knowledge, values, and beliefs that participants bring with them into teaching so that it can work effectively within classrooms and schools as social contexts or communities of practice (Wenger, 1998; Chaiklin \& Lave, 1996; Kirshner \& Whitson, 1997). This process of learning to teach, which Cohen (in preparation) has called "knowing for teaching," is a complex, developmental one, shaped by how individuals participate in these social practices and contexts associated with learning and teaching.

\section{A framework for the knowledge-base of language teacher tducation}

Arguments in favor of this socially-situated perspective and against the acontextual, knowledge-transmission view of teacher learning and teacher education have focused on how teachers learn to teach and how they carry out their work in the contexts of students, classrooms, curricula, and communities. On this basis we have contended that the knowledgebase of second language teacher education must include research that is grounded in the activity of teaching itself, which centers on who does the work, where and how it is done (Freeman and Johnson 1998). In calling for a reconceptualization of the knowledge-base of teacher education, we argue for a core that focuses on the activity of language teaching itself. While we do not want to ignore conventional notions of theory or to replace them simply with knowledge from practice, we do seek a broader epistemological framework that is more directly connected to the activity of teaching itself. Within this framework, both transmitted knowledge and practical knowledge are highlighted and valued to inform and reform teachers' practices. We argue that, for the purposes of educating teachers, theories of second language acquisition, classroom methodologies, or descriptions of the English language as content need to be understood against the backdrop of teachers' professional lives, 
within the settings where they work, and within the circumstances of that work. This framework, we reason, more accurately and more appropriately captures the complex terrain in which language teachers learn and do their work.

We have defined the knowledge-base of language teacher education as including three interrelated domains, which, as a system, describe the sociocultural environment in which people learn to teach and carry out their work as teachers. This framework and the domains within it call for research and documentation. The domains, which are outlined briefly below, are defined as: the teacher as a learner of teaching, the contexts of schools and schooling, and the activity of teaching and learning.

\section{The teacher as a learner of teaching}

We believe that the field needs to recognize that language teacher education is primarily concerned with teachers as learners of language teaching rather than with their students as learners of language. This simple yet crucial shift in emphasis has often been ignored, however. While recognizing that classroom language learning is a complex process, it is obvious that language students learn from many sources, among them the teacher. In our push to understand this complexity, teachers are often portrayed as conduits to students rather than as individuals who think and are learning in their own right. Addressing this view of who the learner is in teacher education is a critical conceptual step to recentering teacher education.

Within the knowledge-base of language teacher education, we must account for how individuals learn to teach and for the complex factors, influences, and processes which contribute in their learning. This requires documented accounts of the role of prior knowledge and beliefs in learning to teach, the ways in which teaching knowledge develops throughout teachers' careers, the role of context in teacher learning, the role of teacher education as a form of intervention in this process particularly in changing teachers' beliefs about content and learners (Freeman \& Richards, 1996). Fundamental to this work, however, is the notion that teacher-learners and their learning processes can only be fully understood if the sociocultural contexts in which these processes take place are explicitly examined as part of that research process. 


\section{The contexts of schools and schooling}

In this domain, we see schools and schooling as the socio-cultural contexts for teacher learning; understanding them is a crucial step in establishing a knowledge base for language teacher education. Schools focus on the physical settings in which teaching and learning take place. But these places where teaching occurs are not neutral or inconsequential to the activity of teaching. Instead, they are a powerful force that impacts on what and how teachers teach.

Schooling focuses on the socio-cultural processes of participation in schools, processes that gain value and meaning for participants through time. Schooling has been documented in such well-known examples as Lortie's (1975) concept of the 'apprenticeship of observation' which describes how teachers' socialization as students throughout their school careers has a major influence on their teaching. From the student perspective, Heath's (1983) study of literacy practices in home, community, and school which identified discontinuities in expectations and norms for social participation. These studies, and many others, have begun to identify the ways in which knowledge is structured in schools and rooted in the social practices of schooling which provides the context in which teacher learning takes place.

Schools and schooling, taken together, suggest that as institutions, schools are powerful places which create and sustain meanings and values. Further, they represent the interpretative environments in which teachers figure out what to do. By including these two elements in the knowledge base of language teacher education, we want to acknowledge that teacher learning and language teaching cannot be separated from the socio-cultural environments in which it occurs. These environments shape what language teachers can do in critical ways; in fact they direct the third domain, the activity of language teaching itself.

\section{The activity of teaching and learning}

Traditionally, as we have pointed out, the knowledge-base of language teacher education in North America has been dominated by disciplinary knowledge, knowledge that is derived from outside the activity of language teaching itself. We argue that, therefore, there is a need for 
grounded research which examines the activity of teaching as it is experienced by teachers and students in classrooms. Doing so will mean coming to understand the rich interplay between what teachers and students perceive and believe, and what they say and do. Such inquiries will need to explore how teachers think (or theorize) about their work, how they transform content to make it accessible to second language learners, how they understand and function within the institutions in which they teach, and how their learning relates to what and how student learn in their classrooms. Inquiries of this nature, particularly when they are undertaken by teachers themselves, will enable us to understand the core of language teaching itself (Freeman, 1999).

To include such investigations in the knowledge-base of language teacher education will entail shifting from the prescriptive stance of what language teachers should know that has dominated the field. It will move us towards a descriptive view that acknowledges existing practices in their positive as well as their less-than-desirable aspects, and that aims to understand why those practices happen as they do. To understand the activity of teaching as it is practiced by teachers in classrooms requires a fundamental reorientation in perspective, as Freeman suggested: "Perhaps we academic practitioners should be asking what is it that they [teachers] know that we [researchers] don't, rather than what is it that we know that they should" (1998/99: 5).

Since the mid 1980's, research in this domain had taken hold in general educational research in North America. One well-known example is the work of Shulman's Knowledge Growth in Teaching Project (Shulman, 1987), in which he and his colleagues argue for a distinction between disciplinary knowledge, which often defines the subject matter to be taught, and teachers' pedagogical content knowledge, or how and why teachers teach content to particular students as they do (e.g. Grossman, 1990). To understand the activity of teaching and learning in our field for example, we must look beyond what teachers know or don't know about grammar to why they teach grammar as they do (e.g. Borg, 1998). If we broaden what we consider to take to be definitional knowledge in language teaching per se, we will expand language teacher education to include a wider variety of paradigms and practices. Such inclusion will no doubt transform the nature of research knowledge in our field by drawing the work of classroom practitioners more fully into our professional conversations (Freeman, 1999). 


\section{The framework as a system}

We see this framework (Freeman \& Johnson, 1998) as a system which describes the socio-cultural context in which teacher learning and language teaching take place, therefore we argue that the knowledgebase cannot be defined as a static set of information and skills. Drawing from the allied perspectives of socio-cultural theory (Leont'ev, 1978; Vygotsky, 1978) as well as situated cognition (Chaiklin \& Lave, 1996; Kirshner \& Whitson, 1997), we contend that how people - in this case teachers and those who are learning to teach-do what they do is critical. In order to understand how teachers take part in and learn from the physical, social, cultural, and historical contexts in which they work, we will have to describe the processes of participation in which they are engaging and how these create communities of practice.

In our framework, we have defined the processes of participation which link teacher-learners to schools and schooling as learning (teacherlearners to schools) and socialization (schools to teacher-learners). In making this distinction, our intent is to highlight the fact that while participation may broadly describe how teacher-learners and schools shape each other, it can be useful to target the differing dynamics when one element versus the other in the pair is dominating the interaction. For example, teacher-learners, whether they are preservice or experienced teachers in inservice programs, engage in learning processes that happen in the setting of their schools through the lens of their experiences of schooling. Thus, learning links teacher-learners to schools and schooling.

From this point of view individual agency matters. For example, teacher-learners are viewed as learning new knowledge and skills in both the context of the teacher education program and the school. Whether they succeed or not is often viewed as a matter of individual ability and effort. By defining the process as teacher learning, we can talk about the sequence and mix of what needs to be learned, how it might best be taught and learned, how it can be assessed, and so on. From the perspective of these settings in which these learning processes take place however, the process can be described differently, as socialization. Socialization is, in effect, a mirror image of this learning process, which takes the features of schools as social, cultural, and political institutions as well as participants' histories within them, their schooling to account for how place and time makes (or un-makes) the teacher. In this balance 
and interplay of teacher learning and teacher socialization, we counterpose individual agency with belonging and collective identity.

Participation links the teacher and students in the activity of teaching and learning. While this view has been regularly studied by researchers in discourse analysis (e.g. Cazden, 1988), it seems to be less prevalent in examinations of teaching methodology or teacher education in our field. By arguing that participation is the central process at work in the classroom, we raise questions about the time-honored notion of causality; namely the commonplace that teaching somehow 'causes' learning. The problem is that, while teaching may not cause learning, neither is the opposite the case. We cannot say that teaching has little or nothing to do with learning, at least under decent circumstances. Therefore we need to unpack the relationship, to study forms of social participation in classrooms that are more or less functional and effective, for learning given the norms of the setting.

As with learning and socialization, we posit that creating communities of practice is a reciprocal process to participation. Defining the process in these terms stems from research in situated cognition which argues that what goes on in a setting-like a classroom or school- can be studied from the standpoint of how individuals participate, as we have said, and from the perspective of the work itself, which these researchers term, "a community of practice." Lave and Wenger (1991: 15) define communities of practice as "groups of people who are informally bound to one another by exposure to a common class of problems or to pursue a common goal." Thus schools as institutions create communities of practice, however the specific locus of that creation is the classroom. Participation of teacher and students in the activity of language teaching creates a community of practice in that classroom.

To understand teacher learning and language teaching from a socially-situated perspective then, we must examine the activity of language teaching through the perspectives of teachers in order to describe their experiences and beliefs about the content and the learning-teaching process. Such research will involve examining schools and schooling as contexts of participation both in and over time, and coming to understand more about schools as meaning-driven environments which shape language teaching and learning. By 'meaning-driven environments', we refer to the multiple ways in which schools create and sustain explications for activity through how they structure participation and the communities of 
practice they value (or silence). Further, such research will require exploring the experiences of teachers as learners of teaching throughout their careers from the time they first participate in the practices of schooling as young children to the socio-cultural contexts in which they practice as teachers.

\section{Recognizing teachers' ways of knowing: the new scholarship}

To understand the activity of language teaching through the perspectives of teachers, it follows that we must gather descriptive accounts of how teachers arrive at what they know, how they use that knowledge in classroom and school contexts, and how they make sense of and reconfigure their classroom practices over time. Over the past decade, the reflective teaching movement (Schon, 1983, 1987; Lockhart \& Richards, 1994; Telles, 2000, 1998; Zeichner \& Liston, 1996) the predominance of action research (Kemmis \& McTaggart, 1988; McNiff, 1993; Somekh, 1993) and the teacher research movement (Cochran-Smith \& Lytle, 1999; Edge \& Richard, 1993; Freeman, 1999) have each helped to legitimize both teachers' experiences and the importance of reflection on and inquiry into, those experiences as mechanisms for change in classroom practices as well of professional development.

How teachers know what they know has been studied in general educational research in North America under the rubrics of the 'new scholarship' (Schon, 1995, Zeichner, 1999) or 'practitioner research' (Anderson \& Herr, 1999). Such efforts reflect a broad-based movement among academic researcher and school professionals to legitimatize knowledge produced by teachers in their own realities as professionals. It includes an ongoing struggle to articulate an epistemology of practice that shows teachers as knowers, as producers of knowledge, and as capable of constructing and sustaining their own professional development over time. Harkening back to process-product research, such work, it is currently argued, has the potential to fundamentally alter the so-called "outsider" or "objective-researcher" knowledge upon which the traditional knowledge-base of teaching is founded, by infusing it with "insider" knowledge. The transformation will come about by including the complex and multilayered understandings of students, cultures, social class, gender, literacy, social issues, institutions, communities, and curricula that teachers 
possess as natives to the settings in which they work (Clandinin, 1986; Clandinin \& Connelly, 1995; Cochran-Smith \& Lytle, 1998).

Much of the new scholarship has been aligned with inquiry based methods, such as critical, feminist, and reconstructionist approaches to pedagogy and curriculum (Cochran-Smith \& Lytle, 1999). These approaches depend on practitioners posing questions that emerge fromand are studied in - their classrooms. Public recognition of the new scholarship has the emancipatory goal of transforming schools and changing equations of power and control which dominate them in order to create more equitable relationships between university-generated research and teacher research.

A compelling example of this new scholarship is the line of research undertaken by Clandinin and Connelly $(1991,1995,2000)$ in which they view 'restorying' experiences as essential to teachers' personal and social growth. Narrative inquiry relies on data that are generated in researcher observation, participant-observation, and observations by other participants which results in stories that are jointly constructed by all involved as teachers 'restory' their experience and researchers offer narrative interpretations based on those stories. In a recent work, Clandinin and Connelly (2000) argue that the value of narrative inquiry lies in the capacity to capture and describe experiences as they occur in the midst of other lived experiences, to look inward, outward, backwards, and forwards at teachers' experiences in order to capture their temporal nature, their personal and social dimensions, and to see them as situated within the places or sequences of places. As such, narrative inquiry has the potential to create new meaning and significance in the work of teachers within their own professional landscapes.

While the new scholarship centers on teachers' experiences, in the bulk of the published work, teachers' voices are validated through the collaborative interpretations with researchers (Golombek, 1998; Olsen, 1995; Connelly \& Clandinin, 1988). While such work is informative for the field as it struggles to articulate an epistemology of practice, CochranSmith and Lytle (1998) contend that only systematic inquiry of teachers by teachers will fully generate both individual and public knowledge about teaching. Furthermore, having teachers articulate what they know and do in their own terms responds in part to calls for the validation of local forms of knowledge (Pennycook, 1989; Edge \& Richards, 1998; Freeman 1999). The ultimate goal of such an endeavor is, of course, to recognize 
publicly teachers' ways of knowing as legitimate knowledge that can rightfully stand with the disciplinary knowledge that has to date dominated the knowledge-base of teacher education.

\section{The role of theoretical knowledge}

Expanding the knowledge-base of second language teacher education to acknowledge the teacher as a learner of teaching, the contexts of schools and schooling, and how the activities of teaching function through participation, does not exclude disciplinary or theoretical knowledge from the knowledge-base of second language teacher education. On the contrary, knowledge of how language is structured, acquired, and used remains fundamental to our understandings of language learning and the activity of language teaching. However, when teacher learning is viewed from a socially-situated perspective, teachers need multiple opportunities to examine the theoretical knowledge they meet in their professional education in the familiar context of the work they do in their classrooms. In professional education, we contend that theories of second language acquisition, classroom methodologies, or descriptions of the English language as subject-matter, need first to be understood within teachers' professional lives and within the settings and circumstances in which they work. When theoretical knowledge is situated within the social contexts in which it is to be used, the interconnectedness of that knowledge becomes evident. When language teachers have multiple opportunities to situate and interpret that knowledge in their work, they engage in a process of sense-making that empowers them to justify their practices in the theories that they understand and can act upon in their own classrooms (Johnson, 1996a).

\section{Conclusion}

When viewed from a socially-situated perspective, we see becoming a language teacher as a complex, socially constructed, developmental process in which formal professional education plays only one small part. Teachers come to teacher education programs with prior knowledge and experiences that shapes what they learn. To understand these learning processes, teacher education programs must recognize the schools in which teachers work and the schooling experiences they have 
had are contexts of participation. These contexts shape in critical ways what teacher learners can and cannot- what they will and will not-do as teachers. This socially-situated perspective on second language teacher education requires a broader epistemological view, one that accounts for second language teaching as it is learned and as it is practiced by those who do it, not simply as it has been defined as others would like it done.

The field of second language teacher education has begun to recognize the socially-situated nature of teacher learning. It now must address several fundamental questions:

- Are we willing to reconsider what we take as the core of what we tell teachers they should know and be able to do in language teaching?

- Are we willing to allow teachers themselves to have a full voice in our professional discourse?

- Are we willing to accept and work to describe the messiness inherent in the day-to-day work of language teaching?

- Do the choices and decisions we have made about the content, pedagogies, and institutional forms of delivery in our teacher education programs reflect the above?

We believe that only when we have carefully scrutinized these questions will our conceptions of what is worth knowing in this profession and how it is best learned be adequately anchored in human endeavor of language teaching. Then the field may be willing to accept a broader epistemological framework that is directly connected to the activity of language teaching itself so that we can better prepare language teachers for the work of this profession.

\section{REFERENCES}

ANDERSON, G. \& HERR, K. The new paradigm wars: Is there room for rigorous practitioner knowledge in schools and universities? Educational Researcher, v. 28, n. 5, p. 12-21, 1999.

BALL, D. Bridging practices: Interwining content and pedagogy in teaching and learning to teach. Journal of Teacher Education, v. 51, n. 3, p. 241-247, 2000.

BORG, S. Teachers' pedagogical systems and grammar teaching: A qualitative study. TESOL Quarterly, v. 32, n. 1, p. 9-38, 1998.

CAZDEN, C. Classroom discourse. Portsmouth: Heineman. 1988. 
CHAIKLIN, S.; LAVE, J. (Eds.). Understanding practice: Perspectives on activity and context. NY: Cambridge University Press. 1996.

CLANDININ, D.J. Classroom practice: Teacher images in action. London: Falmer Press. 1986.

CLANDININ, D. J., ; CONNELLY, F. M. Narrative and story in practice and research. In: SCHON, D.A. (Ed.). The reflective turn: Case studies in and on educational practice. NY: Teachers College Press, 1991. p. 258283.

CLANDININ, J.; CONNELLY, M. Teachers' professional knowledge landscapes. NY: Teachers' College Press. 1995.

CLANDININ, D. J.; CONNELLY, F. M. Narrative Inquiry: Experience and story in Qualitative Research. San Francisco: Jossey-Bass Publishers. 2000.

CLARKE, M. The dysfunctions of the theory/practice discourse. TESOL Quarterly, v. 28, p. 9-26. 1994.

COBB, P.; BOWERS, J. Cognitive and situated learning perspectives in theory and practice. Educational Researcher, v. 28, n. 2, p. 4-15, 1999.

COCHRAN-SMITH, M.; LYTLE, S. Teacher research: The question that persists. International Journal of Leadership in Education, v. 1, n. 1, p. 1936, 1998.

COCHRAN-SMITH, M.; LYTLE, S. The teacher research movement: A decade later. Educational Researcher, v. 28, n. 7, p. 15-25, 1999.

COHEN, D.K. Teaching practice and its predicaments. Ann Arbor: University of Michigan, Ann Arbor. Mimeografado.

COLLINS, D.; GRIFFIN, P.; COLE, M. The construction zone: Working for cognitive change in school. NY: Cambridge University Press. 1989. CONNELLY, F.M.; CLANDININ, D.J. Teachers as curriculum planners: Narratives of experience. NY: Teachers College Press. 1988.

DUNKIN, M.; BIDDLE, B. The Study of Teaching. New York: Holt, Rinehart and Winston. 1974.

EDGE, J.; RICHARD, K. (Eds.). Teachers Develop Teachers Research. Oxford: Heinemann. 1993.

EDGE, J.; RICHARD, K. Why best practice is not good enough. TESOL Quarterly, v. 32, p. 569-576, 1998.

ELBAZ, F. Teacher thinking: A study of practical knowledge. London: Crown Helm. 1983.

FREEMAN, D. Renaming experience/reconstructing practice: Developing new understandings of teaching. Teaching and Teacher Education, v. 94, p. 485-497, 1993. 
FREEMAN, D. The "unstudied problem": Research on teacher learning in language teaching. In: FREEMAN, D.; RICHARDS, J.C. (Eds.). Teacher Learning in Language Teaching. New York: Cambridge University Press, 1996. p. 351-378.

FREEMAN, D. Doing teacher research: From inquiry to understanding. Boston: Heinle and Heinle Publishers. 1999.

FREEMAN, D. Research in TESOL: Another View. TESOL Matters, v. 8.6, n 5, dez. 1998 / jan. 1999.

FREEMAN, D.; JOHNSON, K. E. Reconceptualizing the knowledge-base of language teacher education. TESOL Quarterly, v. 32, n. 3, p. 397-417, 1998.

FREEMAN, D.; RICHARDS, J.C. (Eds.). Teacher leaming in language teaching. New York: Cambridge University Press. 1996.

GOLOMBEK, P. A study of language teachers' personal practical knowledge. TESOL Quarterly, v. 32, n. 3, p. 447-464, 1998.

GROSSMAN, P. The making of a teacher: Teacher knowledge and teacher education. New York: Teachers College Press. 1990.

HANDAL, G.; LUVAS P. Promoting reflective teaching. Milton Keynes: Open University Press. 1987.

HEATH, S.B. Ways with words: Life, language and work in communities and classrooms. New York: Cambridge University Press. 1983.

JOHNSON, K.E. Understanding Language Teaching: Reasoning in Action. Boston: Heinle and Heinle Publishing Company. 1999.

JOHNSON, K.E. The vision vs. the reality: The tensions of the TESOL practicum. In: FREEMAN, D.; RICHARDS, J. (Eds.). Teacher Learning in Language Teaching. NY: Cambridge University Press, 1996. p. 30-49.

JOHNSON, K. E. The role of theory in second language teacher education. TESOL Quarterly, v. 30, n .4, p. 765-771, 1996 a.

KEMMIS, S.; McTAGGART, R. The Action research planner. Geelong: Deakin University Press. 1988.

KIRSHNER, D.; WHITSON, J. A. (Eds.). Situated Cognition: Social, semiotic, and psychological perspectives. Mahwah: Lawrence Erlbaum Associates. 1997.

LAVE, J. The culture of acquisition and the practice of understanding. In: KIRSHNER, D.; WHITSON, J. A. (Eds.). Situated Cognition: Social, semiotic, and psychological perspectives. Mahwah, NJ: Lawrence Erlbaum Associates, 1997. p.17-35.

LAVE, J.; WENGER, E. Situated learning: Legitimate peripheral participation. NY: Cambridge University Press. 1991.

LENNEBERG, E. Biological foundations oflanguage. New York: J. Wiley. 1967. 
LENOT'EV, A.N.Activity, consciousness, and personality. Englewood Cliffs: Prentice-Hall. 1978.

LOCKHART, C.; RICHARDS, J.C. Reflective teaching in second language classrooms. New York: Cambridge University Press. 1994.

LORTIE, D. Schoolteacher: A sociological study. Chicago: University of Chicago Press. 1975.

McNIFF, J. Teaching as leaming: An action research approach. London: Routledge. 1993.

OLSON, M. R. Conceptualizing narrative.authority: Implications for teacher education. Teaching and Teacher Education, v. 11, p. 119-135. 1995.

PENNYCOOK A. The concept of method, interested knowledge, and the politics of language teaching. TESOL Quarterly, v. 23, n. 4, p. 589-618, 1989.

RICHARDS, J. C.; NUNAN, D. (Eds). Second language teacher education. Cambridge: Cambridge University Press. 1990.

SCHON, D. The reflective practitioner: How professionals think in action. New York: Basic Books. 1983.

SCHON, D. Educating the reflective practitioner. San Francisco: JosseyBass. 1987.

SCHON, D. The new scholarship requires a new epistemology. Change: The Magazine of Higher Learning, v. 27, n. 6, p. 27-34. 1995.

SHULMAN, L. S. Knowledge and teaching: Foundations of the new reform. Harvard Educational Review, v. 57, p. 114-135. 1987.

SOMEKH, B. Quality in educational research-the contribution of classroom teachers. In: Edge, J.; RICHARD, K. (Eds.). Teachers develop teachers research. Oxford: Heinemann, 1993. p. 26-38.

TELLES, J. A. Biographical Connections: Experiences as sources of legitmate knowledge in qualitative research. International Journal of Qualitative Studies in Education, v. 13, n. 3, p.251-262, 2000.

TELLES, J.A. Teachers accounts of language variation. Revista de Documentacão de Estudos em Lingüística Teórica e Aplicada, v. 1, n. 14, p. 87-120, 1998.

VYGOTSKY, L. S. Mind and society: The development of higher psychological processes. Cambridge: Harvard University Press. 1978.

WENGER, E. Communities of Practice: Learning, Meaning, and Identity. Cambridge: Cambridge University Press. 1998.

ZEICHNER, K. The new scholarship in teacher education. Educational Researcher, v. 28, n. 9, p. 4-15, 1999.

ZEICHNER, K.; Liston, D. Reflective Teaching: An Introduction.

Mahwah, New Jersey: Lawrence Erlbaum Associates. 1996. 